\title{
Breaking new ground: Reaching out to women farmers in western Zambia
}

Janice Jiggins

Paul Maimbo

Mary Masona

Follow this and additional works at: https://knowledgecommons.popcouncil.org/departments_sbsr-pgy

Part of the Agricultural and Resource Economics Commons, Family, Life Course, and Society

Commons, Gender and Sexuality Commons, Inequality and Stratification Commons, and the International

Public Health Commons

How does access to this work benefit you? Let us know!

\section{Recommended Citation}

Jiggins, Janice, Paul Maimbo, and Mary Masona. 1992. "Breaking new ground: Reaching out to women farmers in western Zambia," SEEDS no. 14. New York: Population Council. 


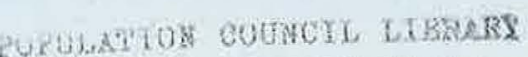

1 Dag Hanmarskgold Plaza

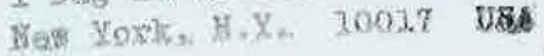

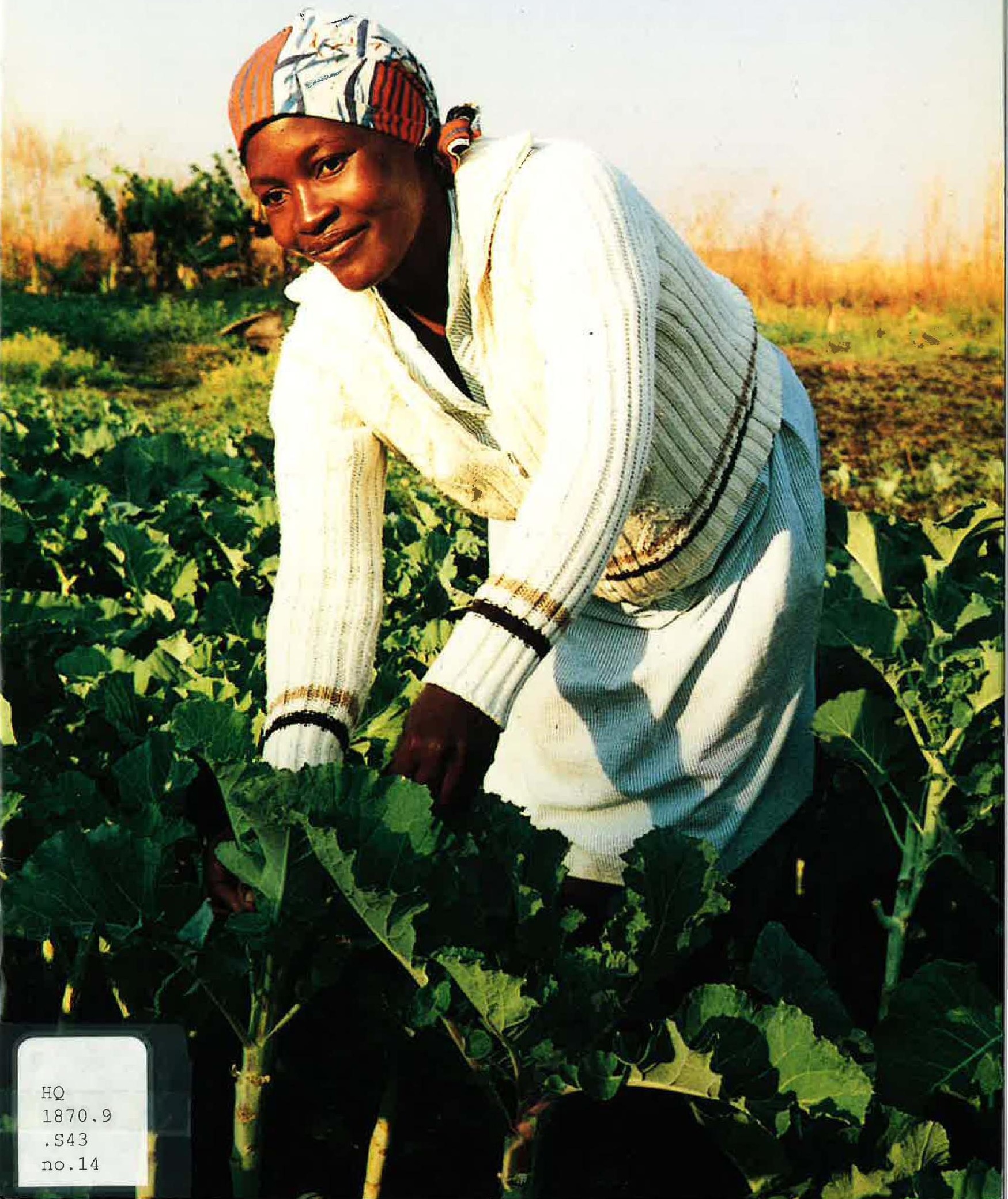


SEEDS is a pamphlet series developed to meet requests from all over the world for information about innovative and practical program ideas developed to address the economic roles and needs of low income women. The pamphlets are designed as a means to share information and spark new initiatives based on the positive experiences of projects that are working to help women generate livelihoods and to improve their economic status. The projects described in this and other issues of SEEDS have been selected because they have served not only to strengthen women's productive roles, but also to integrate women into various sectors of development, both social and economic. All projects documented in the SEEDS series involve women in decision-making, organize women locally, and address broader policy issues which affect the economic roles of women.

These reports are not meant to be prescriptive, since every development effort will face somewhat different problems and possibilities. Rather, they have been written to describe the history of an idea and its implementation in the hope that the lessons learned can be useful in a variety of settings. They are also being written to bring to the attention of those in decision-making positions the vital roles that women play not only in the economies of their individual households but also in the economic life of every nation.
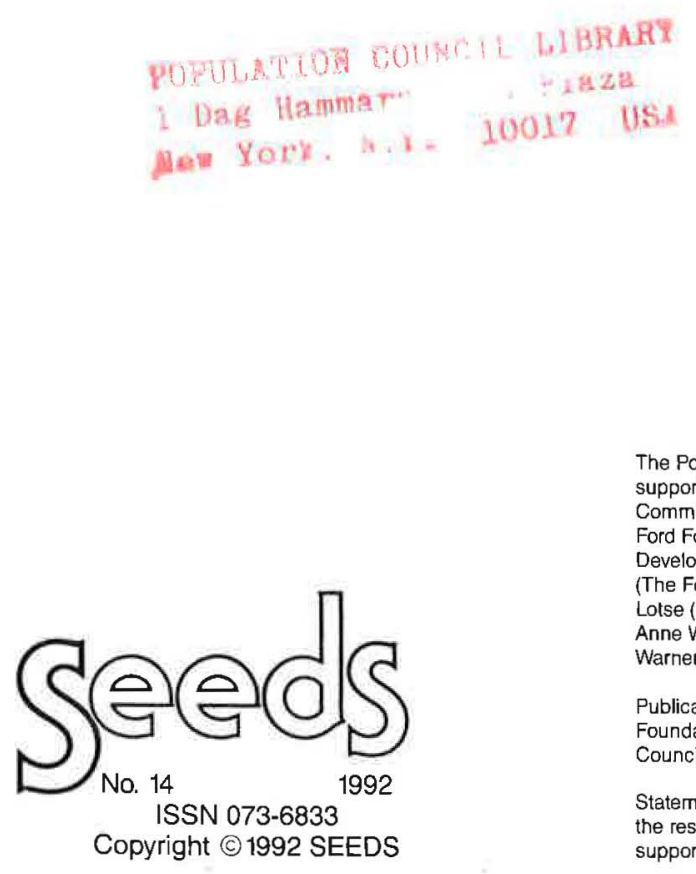

The Population Council provides projecl direction and administrative
support for SEEDS Editorial policy is set by the SEEDS Steering
Committee: Judilh Bruce (Population Council), Betsy Campbell (The
Ford Foundation), Marty Chen (Harvard Institute for International
Development), Margaret Clark (The Aspen Instilute), Anne Kubisch
(The Ford Foundation), Ann Leonard (The Population Council), Cecilia
Lotse (UNICEF), Katharine McKee (Center for Community Self-Help),
Anne Walker (Internalional Women's Tribune Center), and Mildred
Warner (Cornell University).

Publication of SEEDS is made possible by support of the Ford Foundation, the Government of the Netherlands, the Population Council, and UNICEF.

Statements made and views expressed in this publication are solely the responsibility of the authors and not of any organization providing support for SEEDS 


\title{
Breaking New Ground: Reaching Out to Women Farmers in Western Zambia
}

\author{
Story by Janice Jiggins \\ with Paul Maimbo and Mary Masona
}

\section{Introduction}

In sub-Saharan Africa as a whole, it is estimated that women produce more than 60 percent of the food grown for consumption and sale and a large proportion of the nonfood cash crops as well. However, even though women play a major role in agricultural production, crop processing and trading, in Africa (as in other parts of the world) they have received little support from mainstream government agricultural services. Over the last few decades, small-scale projects have been developed throughout Africa to help incorporate women farmers into the mainstream of agricultural extension services. However, only a handful of ministries of agriculture have drawn upon that experience thus far. In this edition of SEEDS, we present one interesting example from Zambia's Western Province. This program is working to change a government agricultural bureaucracy from within by redefining mandates, encouraging attitude change through staff training, broadening village level opportunities and perceptions, and widening technical and economic research agendas. Their experience emphasizes the importance of using a variety of approaches in order to effectively reach women farmers and meet their needs. 


\section{Background}

Zambia is a poor, landlocked country in central-southern Africa. From the perspective of Lusaka, the nation's capital, the Western Province is a remote place lacking the essentials of modern life. Mongu, the provincial capital, is over $600 \mathrm{~km}$. from Lusaka and can be reached by bus or car over partly unpaved roads during the dry season. But the journey becomes progressively more difficult as the rains set in, and the weekly air service is too expensive for most Zambians.

Traveling east to west, the landscape slowly changes from the lightly forested sandy plateau to the escarpment at Mongu, where the land drops abruptly to the floodplain of the Zambezi river. During the rains, the only way to cross the plain is by boat or canoe. The fertility of the land ranges from the relatively prosperous Kaoma area on the plateau, a center of maize production, to the famine-stricken districts of Senanga West in the far south.

In recent years smallholder agriculture in the Western Province has been undermined by Zambia's ailing national economy. Hardly anything works well and many things, from water pumps to clinics, operate below capacity due to the collapse of public services and lack of spare parts, maintenance and supplies. The availability of food subsidies and agricultural inputs, such as fertilizer, also has declined steeply in recent years. Many employees receive some assistance in the form of food rations and other allowances to supplement their salaries, but employment in the formal and government sectors is limited. Women in particular -at all income levels-are coming under increasing stress as a result, since they must care for the sick, feed the unemployed and try to eke out enough cash to send their children to school in the midst of economic chaos.

\section{Women of the Western Province}

Like almost all women in rural Zambia, the majority of women in the Western Province are farmers:

- By Custom. It is a woman's duty to produce food to feed herself and her children and to sell farm produce to meet basic cash needs. She must also serve as a major source of labor in support of the farming activities of her husband and relatives;

- By Necessity. Women head over one-third of all households in Zambia, in law or in fact. Census data suggest that the number of female-headed households is largest in the poorer, more remote rural areas, where agriculture is the sole basis of survival; in some districts, women head more than 60 percent of all households.

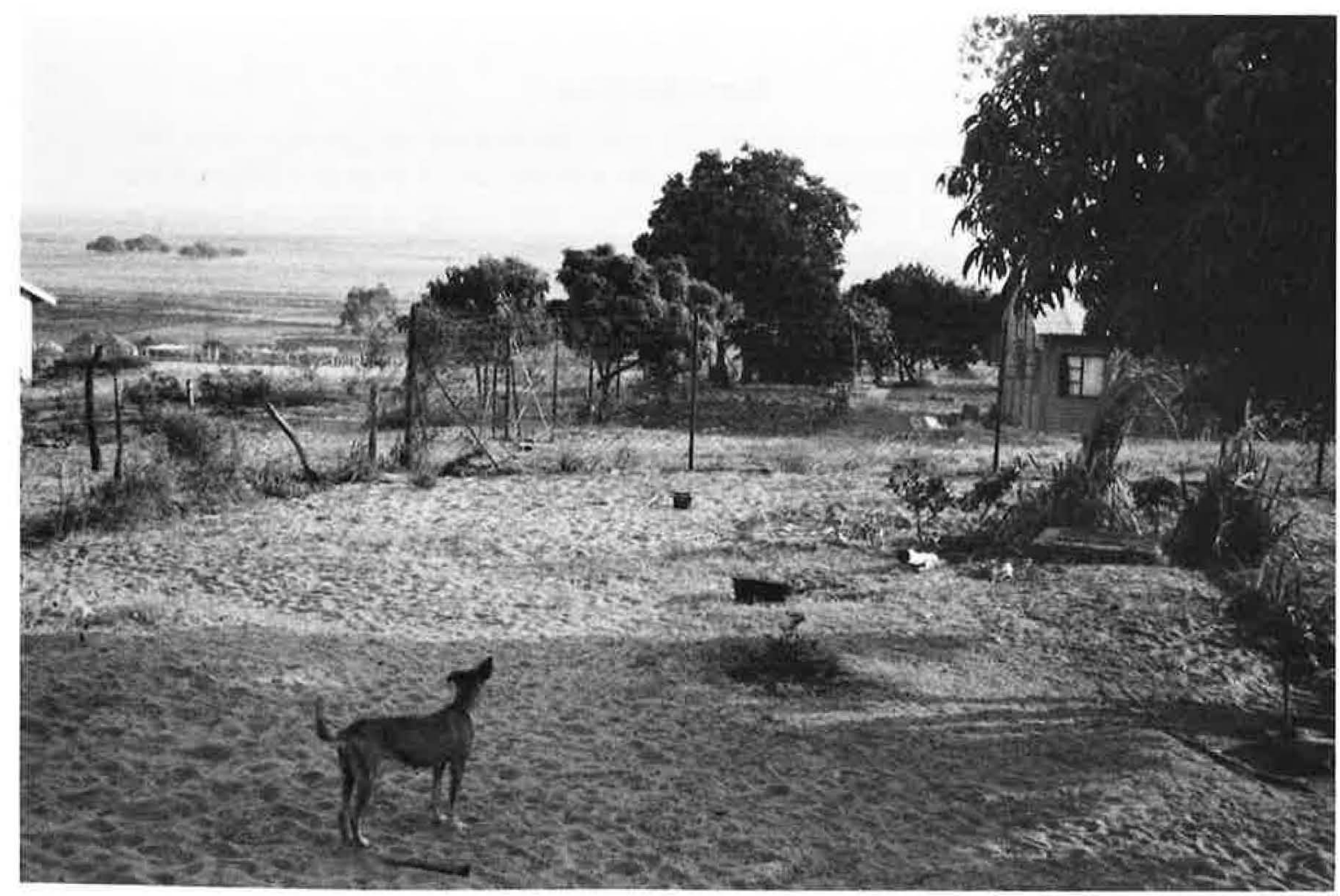


- By Choice. In areas with good soil, efficient agricultural advisory services, access to markets and inputs such as fertilizer and an adequate road or rail network, the introduction of crops for commercial sale, such as confectionery groundnuts, can provide women as well as men with worthwhile income-generating opportunities.

As in many African societies, in Western Zambia a woman's status and her access to land and other resources is based on marriage, lineage and her ability to bear children. In the Western Province, about one-fifth to one-quarter of all married women are in polygamous unions. Cowives typically live in different villages and are visited by their husband in rotation. Villages tend to be small, with less than 100 residents, and are scattered. With perhaps less than 20 households per village, and many men absent in search of paid employment. Many adult women head their own households and a large proportion of these household heads are divorcees.

One of the implications of this situation is that traditional community support for the most vulnerable families is becoming weaker, and women raising children alone are particularly vulnerable; they become more isolated socially and have fewer relations on whom to call for help with immediate needs, such as cash, labor or help with household chores. Under such circumstances, women often experience a sense of abandonment and despair. As a woman from Kweseka village in Mongu District laments, "We have been forgotten by the world."

Land use in the Western Province is controlled by community leaders. As the province is sparsely populated, it is easy for both men and women to obtain land for cultivation and grazing, but there is localized competition for plots in the best and most accessible areas. In this part of Zambia, the basic constraint to farm production is labor-particularly women's labor-not land. Women make up the main agricultural work force in the Western Province, and men and other family members usually have a priority on the use of their labor. While some men do help women to clear land for food cropping, they spend most of their time tending their cattle, fishing, looking after their own food plots and on cash cropping.

According to case studies, during the short rainy season women spend over ten hours a day on domestic and field work whereas men generally spend considerably less time working on the farm. Because of this traditional division of labor, a

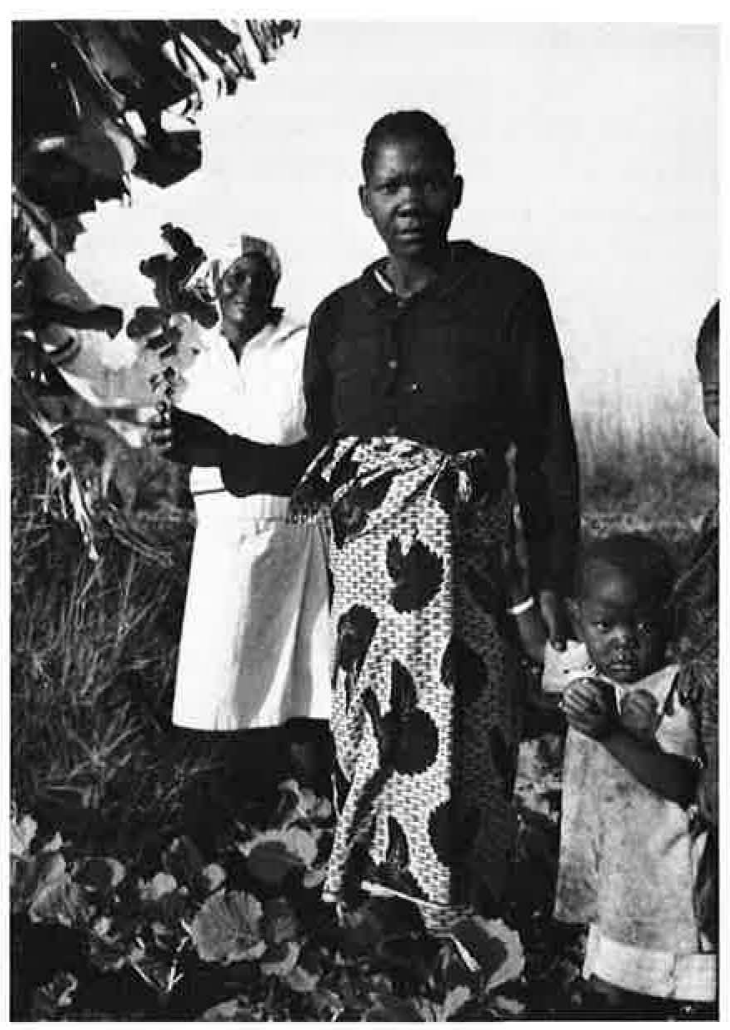

married woman farmer may still face a labor shortage even when her husband is in residence. In order to cope at all, women often form mutual aid work parties because relatively few earn enough cash to hire labor. In fact, most of the women who work as hired laborers head their own households; but the little cash they earn must be balanced against the lower yield they get by neglecting their own crops.

Food preparation also takes a lot of women's time. The staple food-whether maize, millet, sorghum or cassava - is pounded into flour and then generally consumed as a thick porridge. But hammer mills are rare and hand-pounding arduous, so whenever possible households prefer to sell their own crops and buy milled breakfast meal (a refined maize flour). Because of the time required for processing by hand, rice is rarely consumed at home; the whole crop is usually sold. Women also must devote time to other domestic chores as well, such as collecting water and fuel and to child care.

Few sources of income besides farming are available to women in Western Zambia. The sale of mats and baskets, wild fruits and mushrooms, bananas, mangoes and small-scale fishing activities provide occasional income for some. Studies show that women spend their income on, in order 
of importance, food, clothing and schooling for their children.

By far the most common source of cash for women is the brewing and sale of beer. Surveys suggest that three-quarters of all women brew regularly, mainly for sale but also to mobilize and reward hired labor. On average, women brew four to five times a year, mainly in the dry season. Net profits vary a great deal but $100 \mathrm{kw}$. (U.S. \$2-3) for each batch brewed is not uncommon.

In Western Zambia, constraints on the amount of time women can devote to their own crops, together with a lack of cash, limits their ability to purchase food. This situation is leading to increased cultivation of cassava as a food crop, and when converted to beer, as a cash crop. Cassava is a relatively hardy crop that needs little attention once it has been planted, and the roots can be stored in the ground until needed. Although it is rich in carbohydrates, it is poor in protein and minerals. So in addition to the undernutrition already widespread in the region, malnutrition is reportedly increasing, especially among children, who find it difficult to eat enough of the bulky, starchy cassava necessary to gain sufficient nutrients.

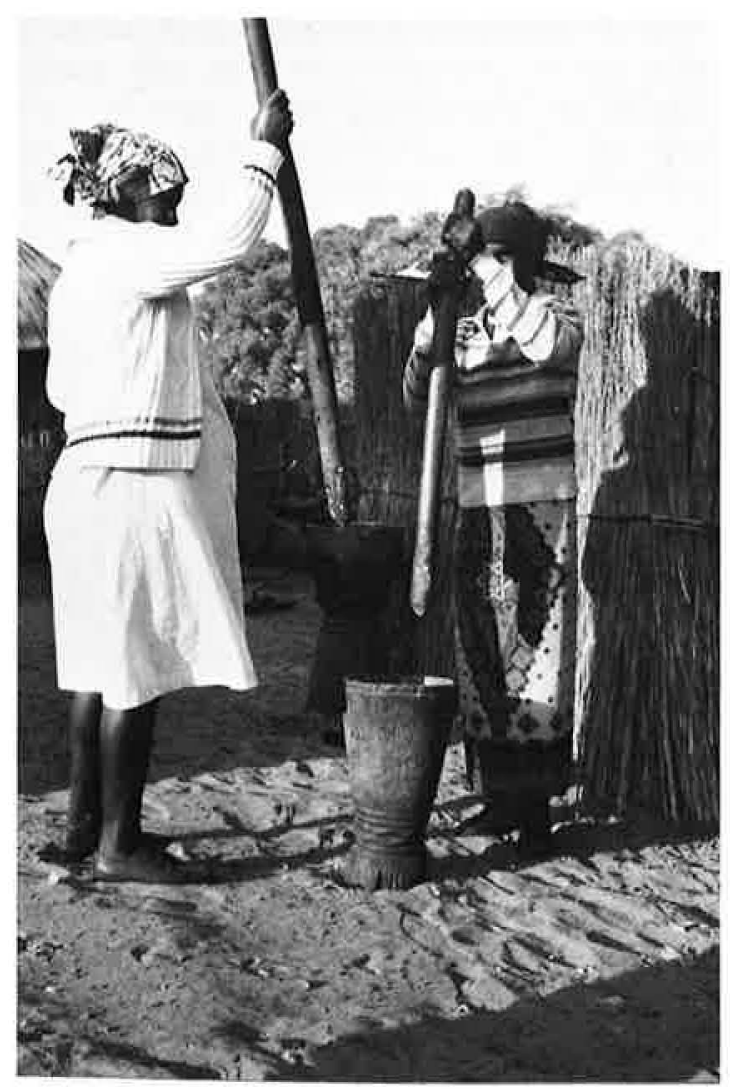

\section{Agricultural Extension and Women Farmers}

In Zambia, as is the case throughout Africa, policymakers and service providers have neglected the role of women in agriculture because large, conservative, male-dominated bureaucracies have regarded women's work on farms as simply "what women do." The real contribution that women's farming makes to family welfare and national food security has remained virtually invisible. In addition, because of the underlying assumption of governments and technical assistance agencies that modern farming means "male" farming, large-scale agriculture and livestock surveys have rarely captured data on factors such as women's labor input, women's management practices or the crops that typically only women grow.

While women continue to be neglected by mainstream agricultural development efforts, their role in farming is becoming more critical. Complex changes in social and economic life are leaving more and more rural women as sole provider for the family. While not all female heads of households have the same problems, the excessive demands on their time and energy often leave women socially isolated as well as economically marginalized. The competing demands of farm work and the care of children and other dependents can lead to the rapid deterioration of family welfare and security.

Although numerous rural women somehow do manage to prosper, the majority experience hardships that mainstream agricultural services have been slow to recognize or respond to. Among the most important are:

- Heavy work loads, long working days and little access to the cash needed to hire labor;

- Lack of access to credit and financial services, usually related to problems of mobility, women's status under the law and the type of financial services offered;

- The gender of agricultural extension agents (mostly male) and their reluctance to break cultural taboos about working with women who are not family members and their tendency to hold stereotypic views of what women can and should do;

- Lack of access to training (particularly in critical agricultural activities such as ox plowing) fertilizer and other inputs, again often related to the gender of agricultural extension personnel; and, 


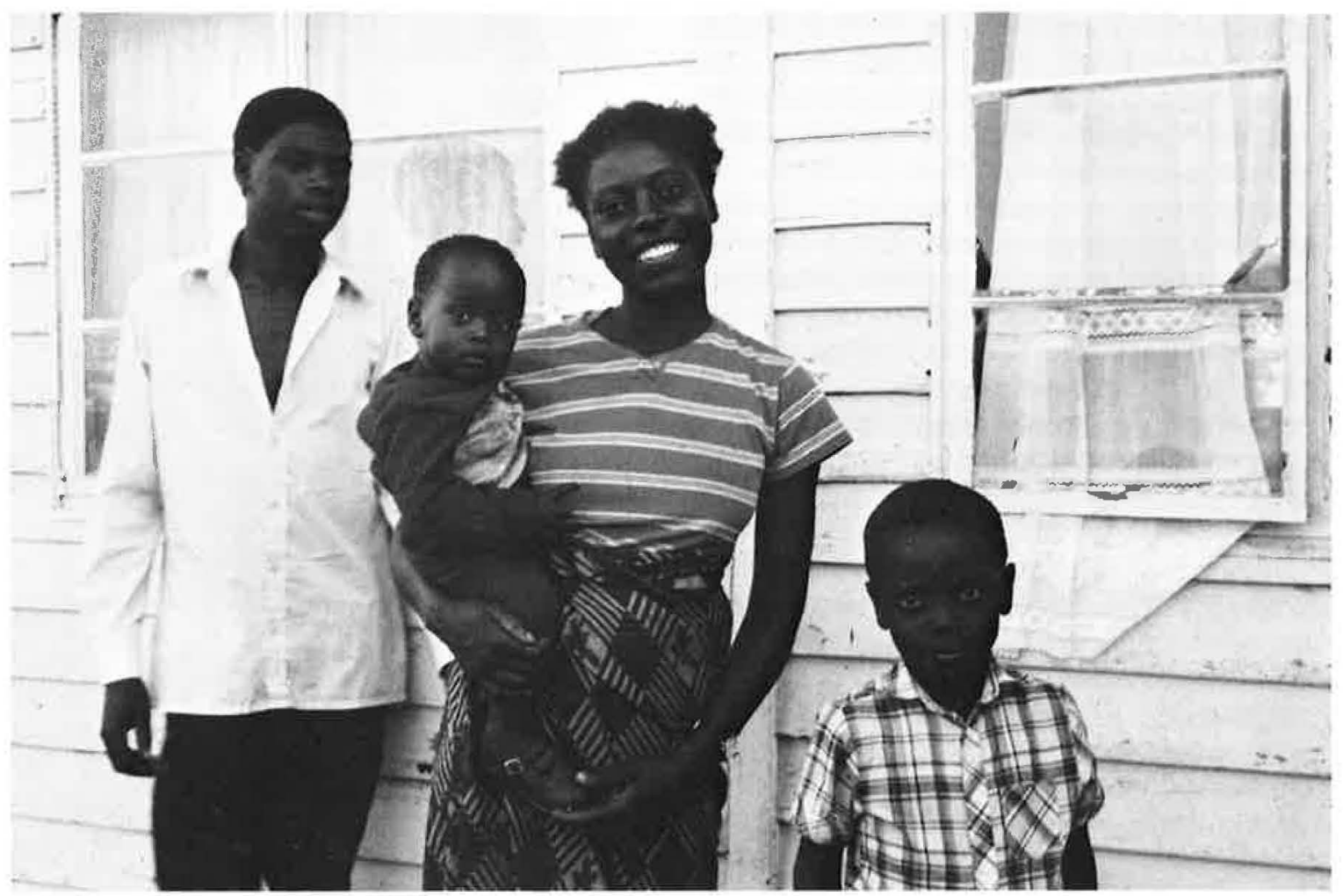

- Women's own lack of confidence in asserting themselves, taking on new roles and challenging attitudes, despite the major changes taking place in the customary organization of life around them.

Although the government of Zambia broadly supports special efforts to promote women's development, agricultural policy still does not explicitly recognize the role of women farmers. Since the mid 1980s, women researchers at the University of Zambia, "Women and Development" project staff and the Senior Home Economics Officer in the Ministry of Agriculture and Water Development have joined together to develop ideas and strategies to: 1) identify desired policy changes, 2) bring relevant experience to the attention of policymakers, and 3) stimulate official recognition of women's contribution to agriculture and greater access to government agricultural services. They are closely watching the work of the Women's Extension Program (WEP) in Western Zambia because, unlike many other women's extension projects, its primary task is not to provide services directly to women farmers. Rather, it is designed as a strategic intervention of limited duration that will bring about change within the mainstream of the Department of Agriculture's programs through advocacy, training, information, statistics, persuasion and liaison.

\section{Origins of the Women's Extension Program}

The Women's Extension Program (WEP) is located within the Home Economics Section of the Department of Agriculture, although operationally it falls under the overall direction of the Provincial Agricultural Officer. The authority of the PAO in turn opens access for the WEP to the training and extension activities of the Department and to the Research Section. The program's location in Home Economics and its design are the result of earlier experiments to find the right point of leverage for the program to enable it to build linkages within the Department and initiate effective methods for changing attitudes.

The Home Economics Section had been providing training to women on topics such as food preservation and storage, nutrition and child care since 1971, but as far as women's farming activities were concerned, it faced two handicaps: reliance on specialists in other sections for technical advice and the need to use the Department's existing extension field staff in order to reach women. To achieve its own goals, the Section thus had to develop effective mechanisms for working with and through other people, the majority of whom are men.

In the Western Province, most of the Department's 200 extension field staff, called agricultural 
assistants (AAs), are male. The Provincial Home Economics Officer, Mrs. Elizabeth Kazungo, notes: "Really, it has always been a struggle. The men feel that anything to do with women farmers and home economics is not their concern."

Moreover, in a system based on individual farm visits, there are far too few agricultural assistants to provide adequate coverage. The ratio of AAs to farm households is around 1:450. A survey in five areas of the Western Province revealed that while an AA had never visited at least 40 percent of male household heads, more than 80 percent of female heads of households had never received a visit. The AAs tend to excuse their neglect of women farmers by hiding behind tradition. They say: "We do not feel comfortable talking to a woman. It is not our custom. Husbands and boyfriends might accuse us."

A real breakthrough occurred in the early 1980s when the Department launched a special rice growing project with support from the Dutch government. The project soon recognized that it would have to involve women more closely if it were to succeed. A Dutch female extension officer was recruited to conduct a survey of local women: their workloads, contribution to rice production, attitudes toward agricultural education and access to the male AAs. Her report provided the hard data needed to open up discussion of women farmers and their needs. In addition, the presence of a female "expert" heiped legitimate issues of "women in farming" among the male provincial staff, both expatriate and local.

Following the survey, the Dutch expert was asked to form the women living in the project area into groups to more easily provide them with training and extension services. She began by enlisting the help of female technical officers working on the project, such as Mary Masona who was later to head the WEP. Mrs. Mason was then working as an animal husbandry officer, advising the project on the draft oxen needed to plow the rice fields. Together with other female project staff, they began to mobilize the women farmers into groups. It was also felt that male AAs would be less reluctant to work with groups of women than with individuals.

The group approach proved to be very successful. As Mrs. Kazungo says: "It fits our way of doing things here. Soon we learn to feel comfortable together. There is so much support from one another." But the experience also convinced the Department that it needed a more strategic intervention that could address both the attitudinal bar- riers among male staff and some of the practical difficulties. After further analysis and discussion, the Women's Extension Program-while located within the Home Economics Section-was attached to the ongoing Extension Training Program, since the link with training would strengthen WEP's ties with the mainstream agricultural extension program.

The new program had two main training objectives. The first was internal and involved adding a short course to the training program for the male agricultural assistants in order to make them aware of women's roles in agriculture in the Western Province. The second was external: to develop and run mobile courses for women that relate directly to women's farming. In 1986, Mrs. Mary Masona was appointed the first WEP Coordinator.

It was a challenge but I am always running -l like to get things done! What's more, I come from this area and I know the traditions. I have ten children and I know the hardships of women here.

Mary Masona

The WEP set the following goals:

- To collect data on women in agriculture and related issues;

- To help members of the Department appreciate the importance of reaching women farmers;

- To advise the Department on how to effectively reach women farmers;

- To sensitize field staff to the importance of women's farming;

- To assist in the planning and implementation of development projects and to assess their effects on women;

- To provide assistance in setting up and running women farmers' groups.

\section{Putting Women on the Agenda}

The WEP operates primarily through the existing structures, staff and projects of the Department of Agriculture. Apart from the coordinator, the WEP has no staff of its own. Its influence is based on persuasion and cooperation rather than formal power, and bureaucratic context shapes the way the program works. Mrs. Masona defines the WEP as a "strategic booster," to help get women into the mainstream. 


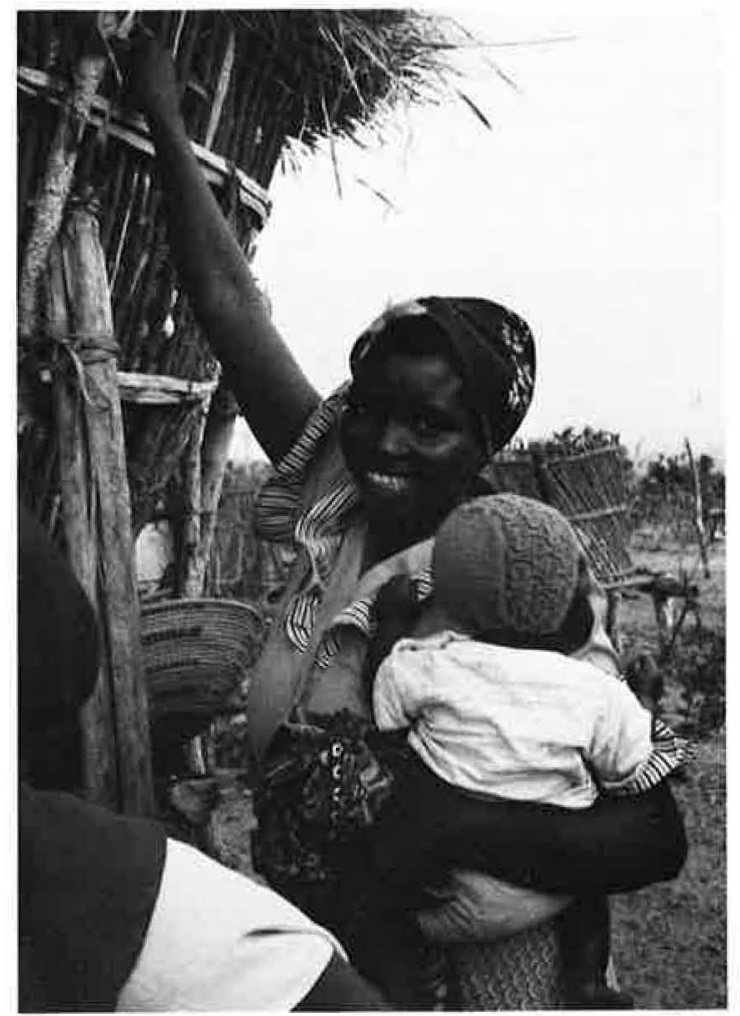

The coordinator, therefore, works through her provincial and district colleagues to build networks of understanding and support with other sections. An important first step has been helping district and field level colleagues become aware of the importance of women's involvement in agriculture within the province.

Departmental Coordinating Committee. The Departmental Coordinating Committee (composed of section heads and project coordinators) is an important forum for maintaining interest in the goals of the WEP. The committee tries to meet regularly to coordinate transport, share ideas and revise plans. Initially the committee relied on the women members for ideas about how to reach women farmers. But, as Mrs. Kazungo notes, male colleagues now are gaining the confidence to contribute their own suggestions. By avoiding confrontation and by concentrating on presentation of data and results of field studies, the WEP has been able to offer some subtle gender training within the committee meetings themselves. The WEP coordinator adds, "Now they come to us when they need our help or have an idea. They can see that we have something to contribute to their work, too."

Mobile Training. The WEP also encourages colleagues within the Department to deliver field level training in ways that are compatible with women's time constraints, domestic responsibilities and educational experience. Mobile training programs offer an alternative to more traditional residential courses and are proving to be a success with both staff and farmers. The mobile training is run by the AAs, with support from district or provincial specialists, over a two or three-day period, at a time and place convenient to the participants. Each course deals with a specific topic, such as fertilizer application or row planting of hybrid maize. Unlike the formal, lecture style training offered in residential courses, the on-site courses use a mix of methods, including practical instruction, question-and-answer, discussion and on-the-spot trial of what has been learned.

At first the WEP emphasized women-only courses because women were reluctant to attend classes where men were also present. But the aim has always been to integrate women more fully. As Mary Masona says: "If women are separated they will always be on their own." Nevertheless, WEP has also recognized that women-only courses are needed on topics of special concern to women, such as food preservation, and on skills that men already possess and women want to learn, such as ox-plowing.

Monitoring. The WEP encourages agricultural assistants to monitor women's participation in residential training, mobile training courses, field days and demonstrations. A target of 50 percent female participation has been set for mixed courses (i.e. those with both male and female participants), field days (opportunities for farmers and AAs to review progress on a host farmer's field) and demonstrations, and the results are quite encouraging. During the $1989-90$ season, women's participation in all courses reached close to 40 percent.

As a Mongu-based AA explains, "Now women are coming willingly for courses and there are no suspicions of me, even if I meet a woman farmer in her field. And the women accept me because they see I have knowledge that is useful to them."

\section{Breaking Through Traditional Barriers: "Plowing? We're Doing a Job That Was Taboo"}

A real success for the WEP has been to provide women with access to training in ox-plowing. In the past, women did not plow themselves; it was a man's skill and a woman's touch was thought to bring bad luck and sickness. Today, 
with more women being sole providers, there is a growing recognition that women must also learn this skill.

Use of oxen for plowing is critical to increase crop yields from rainfed farming, but a number of cultural, practical and financial barriers have barred women from use of draft animals. Although women rarely herd or corral cattle, almost one-third of all women in the province probably own cattle at some point in their lives through inheritance or as payment of bride price. Nevertheless, it is a widely held belief among men that women have little to do with the care and management of cattle and that they are not interested in keeping them.

One of the difficulties in women's ownership of cattle is the cost of caring for them (hiring herd boys and people to shift the corrals, buying medicines and so on). Women who can afford to plow are usually forced to enter into complex borrowing or hiring arrangements to get the work done. As a result, women's fields are usually plowed after the men's - which typically means poorly and latewith commensurate low returns in terms of yields.

To help women learn to plow, the WEP has had to leverage and guide coordination among a number of Department sections, including animal draft training officers, the agricultural assistants and the women farmer groups (described below).
The First Step. At first, the very idea seemed a joke. An ox-plowing training center had been established in the province in 1983 , but no one ever thought about training women farmers. The expatriates involved in the ox center were afraid of breaking cultural taboos and the agricultural assistants simply thought that women would not be able to learn such a skill. However, when the rice growing project began in the area, it created a lot of extra work for women.

A survey of women's work in rice production carried out by the Dutch advisor had revealed that a number of women already owned an ox, or even a team, or had access to one through relatives. However, they had no control over the oxen's use and lacked the skill to plow themselves. Quietly, a few women farmers involved in the rice project got together with Mrs. Masona and her colleagues and began to practice plowing. When the next agricultural show came along, the women demonstrated their skill to the great surprise of the onlookers! The first step had been taken toward training women in ox-plowing.

Growing Recognition. The Department also realized that special ox-drawn implements, especially cultivators and ridgers, were needed or weeds would halt the spread of rice production. In October 1989, work began to test and introduce low-cost ox-drawn implements. Through liaison

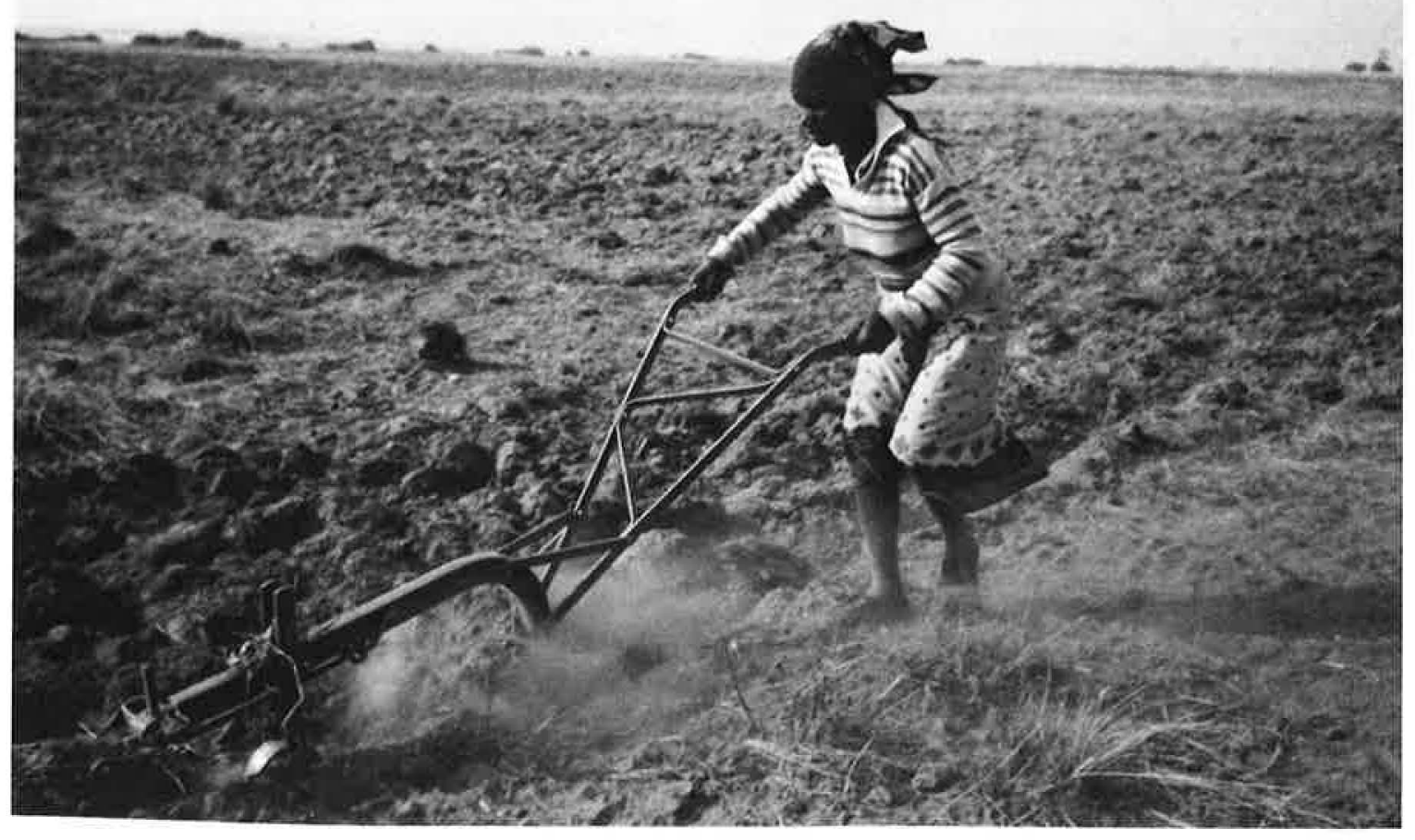




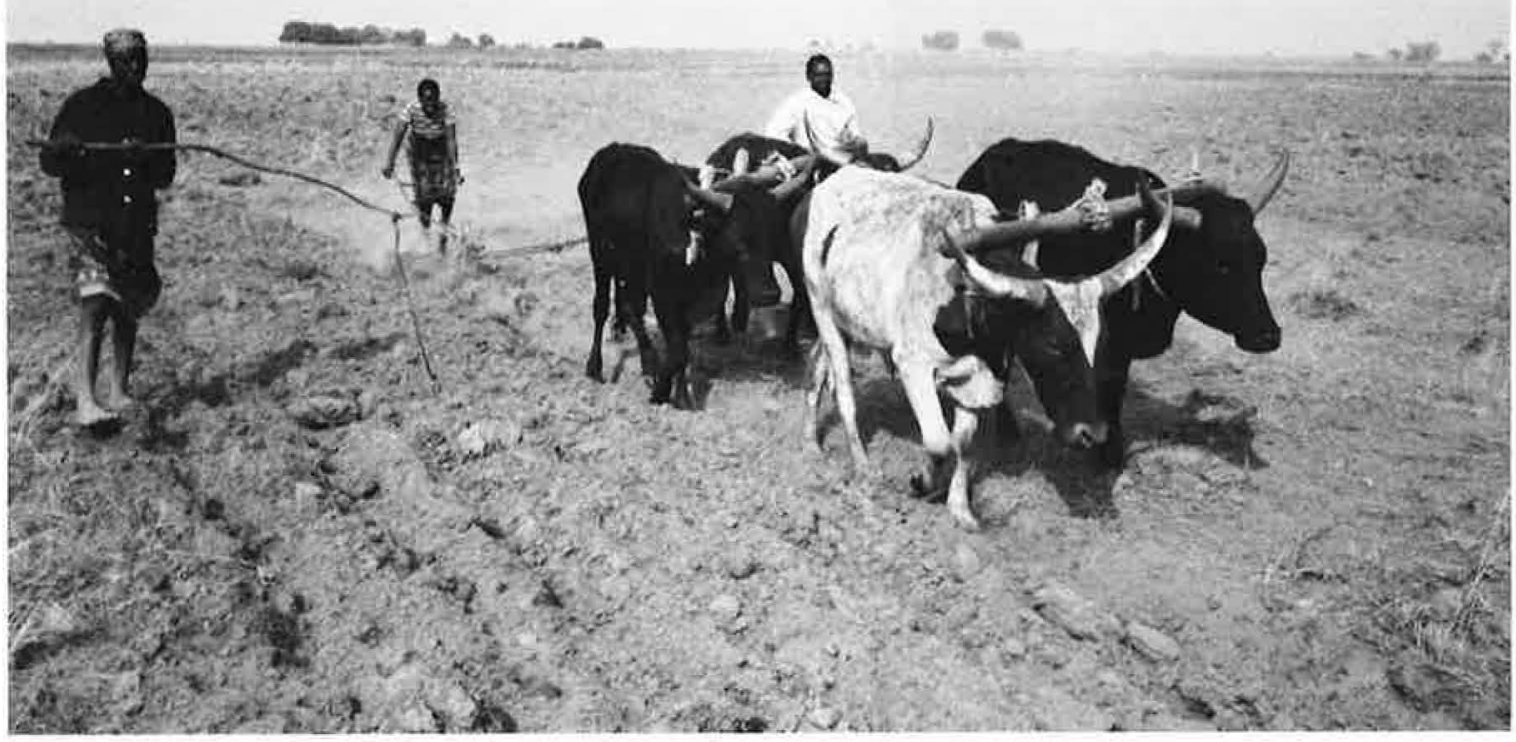

with the WEP, women's groups are becoming involved in the testing program. Today, ox-plow training is routinely provided to women's groups through mobile courses and by the agricultural assistants. Increasingly women are being hired as teams to plow for others. These women's plowing teams are establishing a good reputation as conscientious and effective handlers of oxen.

Changing Attitudes and Aspirations.

The women themselves are enthusiastic; they are proud they have acquired this "difficult," male skill. They also recognize it as a breakthrough in the way they are regarded within the community. Although many local women lack access to oxen and equipment, and are unable to take out the large loan needed to buy them, they attended the courses because "maybe one day I will buy an oxen," or "perhaps my daughter will do better than me in life and then I can help her to plow" or "if the maize is good this year, maybe my group will decide after all to buy a team and the necessary equipment."

Women's participation in ox-plowing and other changes have not come about solely as a result of training and persuasion. They have been reinforced by two other operational innovations within the Department: the People's Participation Project and the Adaptive Research Planning Team.

\section{Building Women's Confidence and Organizational Strengths}

One of the lessons of the rice growing project was that group mobilization and support is essential to: a) provide a culturally acceptable point of contact between women and the male agricultural assistants; b) encourage women to make use of existing services; and c) develop women's organizational skills and leadership capacity at the village level.

Initially activities of the women's groups were coordinated directly by the WEP program. Later they were formalized as part of a centrally-supervised People's Participation Project (PPP), with support from the Food and Agriculture Organization (FAO) and the Dutch government. However, coordination of the PPP proved difficult within the WEP framework, in large part because the WEP has neither staff nor a mandate to become directly involved in field activities.

The Department therefore seconded Mrs. Lydia Ndulu from within the provincial Department to serve as the Provincial Coordinator of the PPP. She also works within the Home Economics Section. With training in nutrition, home economics and horticulture and considerable experience in the Department, Mrs. Ndulu had sufficient standing among her male colleagues to be accepted as 

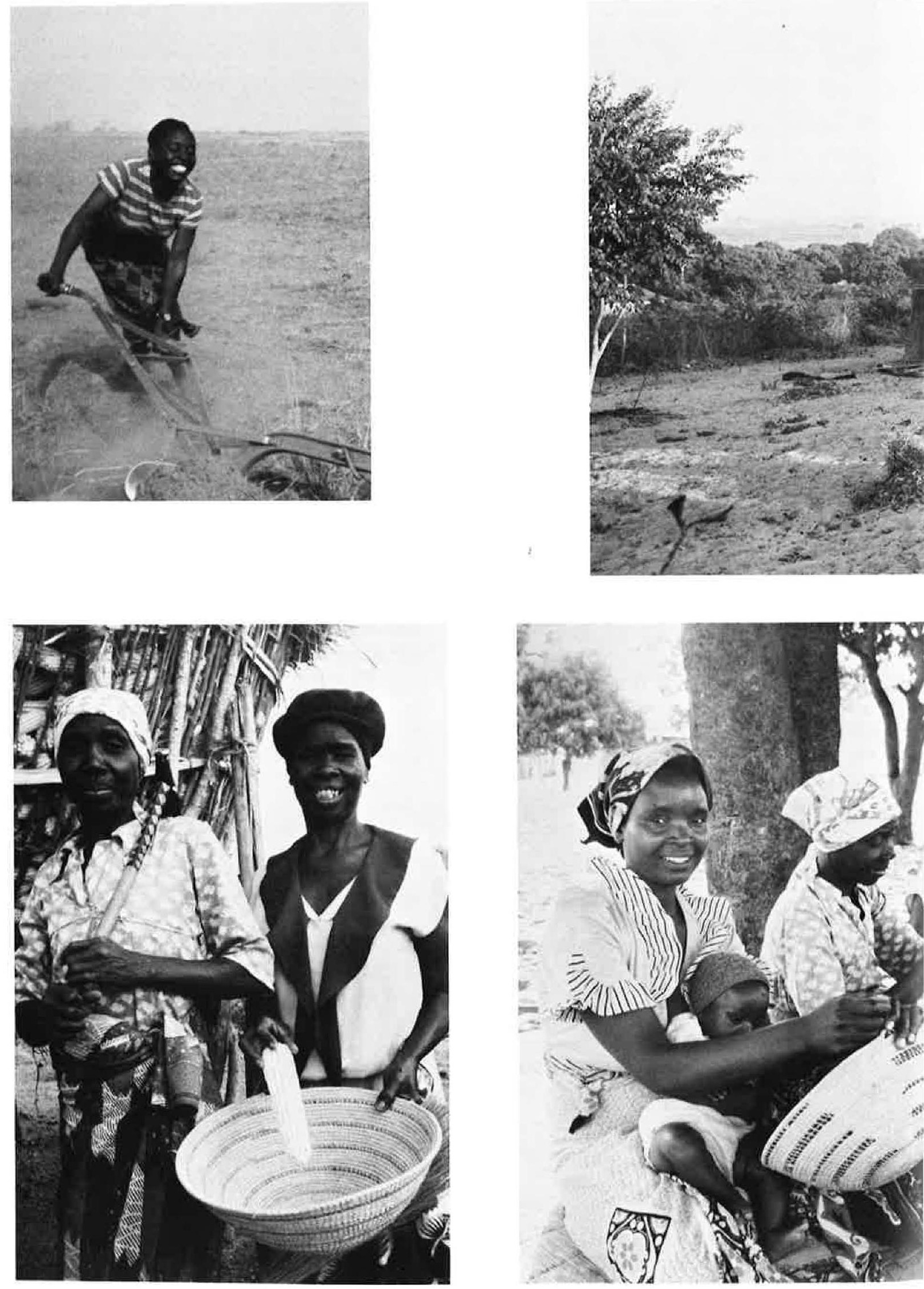

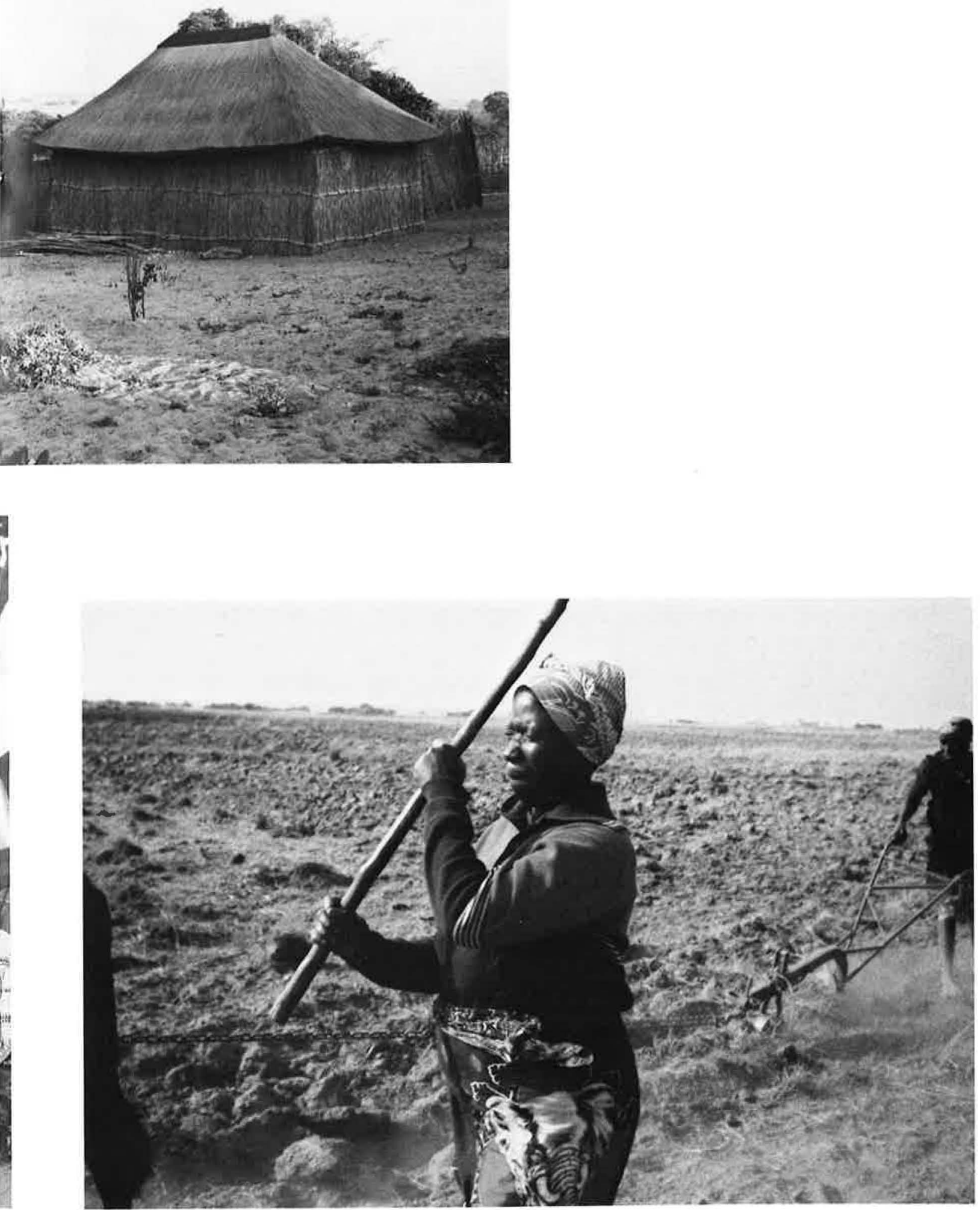
an agricultural professional, not just the leader of a special "women's project."

Group Development. Lydia Ndulu is convinced that women's best option is to get access to existing services and support structures through the mechanism of group development. But before this can happen, the women have to become aware of their rights, develop organizational strengths and leadership ability, and overcome feelings of ignorance and shyness.

The PPP began in February 1984. By 1988 , 24 groups had been established in the three districts of Kaoma, Mongu and Kalabo. By mid-1990, there were 130 groups with 1,144 women members and 507 men. In some groups, all the members are women but most also include men. Village men initially resented the emphasis on women: "Why are you segregating us?" they demanded. As Mrs. Ndulu says, "It was quite a bit tough to explain." But the PPP has found that in the long run the inclusion of men helps the groups because, for one thing, it assures the AAs that they are not breaking cultural taboos when they work with the group. Male members can also defend the groups to others and, because they have better access to male officials, they can even advance women's causes more effectively. But the PPP has been careful to ensure that men do not take over: no male member can be a group office holder.

Women Speak to Women. At the village level, local women have been recruited to work as group promoters. They support the women farmer groups and mobilize more women to join. One group promoter from Limulunga, who joined the PPP right from the start, recalled that at first, she found it very difficult: "When we went to a village to talk to the Village Headman and the Party Section Chairman, I felt shy and did not know how to explain what it was we wanted to do. We told them that the project was for 'women who are lame' but they were suspicious of our motives. We also did not know at first how to go about mobilizing the women and supporting them." Now she is sure village women would always prefer to first speak to another woman, one from the same background as themselves. "They have many problems they feel shy to discuss with a man. They can ask me questions about feeding their children, about tools and skills in farming, without feeling ignorant and stupid. If men had been running this project, we wouldn't have progressed so far."

Lydia Ndulu confesses that, although it was difficult at first, the men in the Department have

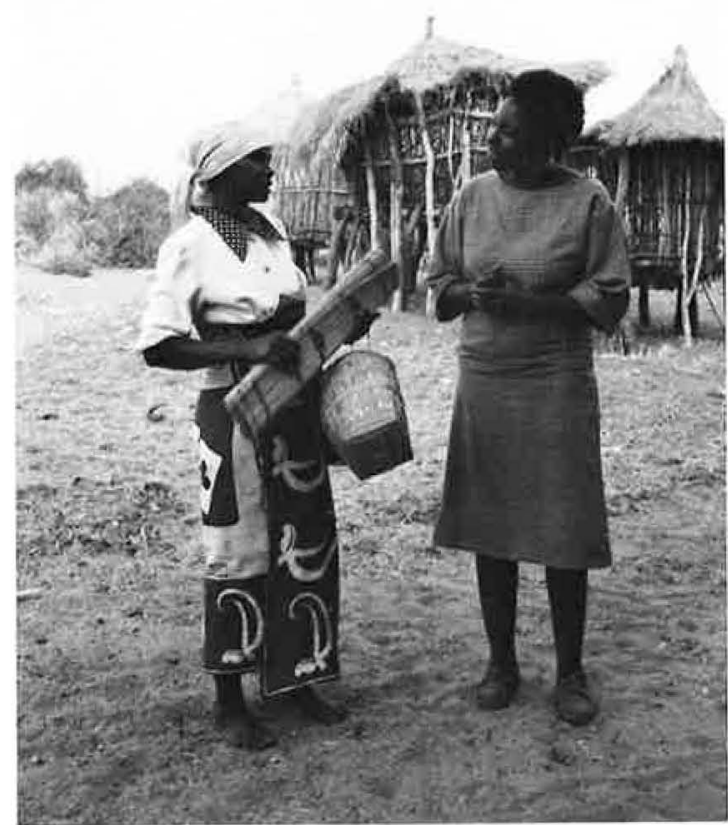

come around. Initially, they regarded the group approach and the emphasis on women as "FAO ideas," but "they have come to realize that it benefits the Department's work and makes it easier for everyone to work with the people."

\section{Impact: "We Don't Want to Starve"}

Rosemary Ntoka is the leader of a group in Lilu village in Limulanga area of Mongu District. She is a farmer with two children and she is pregnant with her third. Is she happy with the PPP? "Yes, of course! To survive, we women have to learn new ideas and methods. We don't want to starve! And I am interested in the group because this way we share our problems, we share ideas and we learn together."

Some Successes. In Kweseka village, one of the earliest groups is now thriving. It began in 1984 with nine women members. Their first group savings came from cultivating a maize plot together. Then they tried wheat, maize again, sweet potatoes and cashew seedlings. For the first time in their lives, they received help from the agricultural assistant and learned how to plow with oxen.

In 1988 the Kweseka group opened a consumer shop, investing $200 \mathrm{kw}$. (U.S. \$20) from the 
group's savings account. By 1990, it had generated a profit of $4000 \mathrm{kw}$ (U.S. \$105). The group also makes and sells brooms, baskets and knitted berets. Group savings are deposited in a post office account reserved for future investments and working capital. (Group members are also encouraged to establish separate accounts of their own.) The group plans to begin buying and selling breakfast meal (refined maize) as soon as they have enough saved.

Some Difficulties. Ishekendo, another group in the area, is struggling. The village lacks water and agricultural opportunities are fewer. The women tried to grow rice but it became infested with black maize beetles. They too have been taught how to plow, but they have no opportunity to borrow oxen and equipment and they are afraid to buy their own animals because they fear the thieves who prowl along the nearby road at night. However, with the help of their group promoter they have improved the marketing of their craft products. The extra income has helped them to buy the supplies needed to grow maize and, when the rains are good, they have produced good harvests. Though their gains have been modest so far, the women are positive: "We get a lot of strength from being together. The agricultural assistant here is a lady and she gives us a lot of encouragement. She taught us how to make gari [the West African name for dry cassava flakes]. We feel good about learning new things. Nobody talked to us before."

\section{Taking Up Women's Agricultural Priorities}

An increasing number of studies have demonstrated that a lack of understanding of how small farmers, both men and women, actually operate their farms lessens the efficiency and effectiveness of agricultural research. To develop this understanding, an Adaptive Research Planning Team (ARPT) has been established in the Western Province as part of a national program under the Research Section of the Department of Agriculture (see Figure I). ARPT's mandate is: a) to work with small and emergent farmers to provide them with the technical and economic information needed to improve production; and b) to carry out adaptive research with farmers on their own fields.

The team works closely with trial assistants (all men) based in the field and with the agricultural assistants. From its inception in 1985, part of ARPT's mandate has been to include women farmers in its work and to pay special attention to farm households headed by women. It was rec-

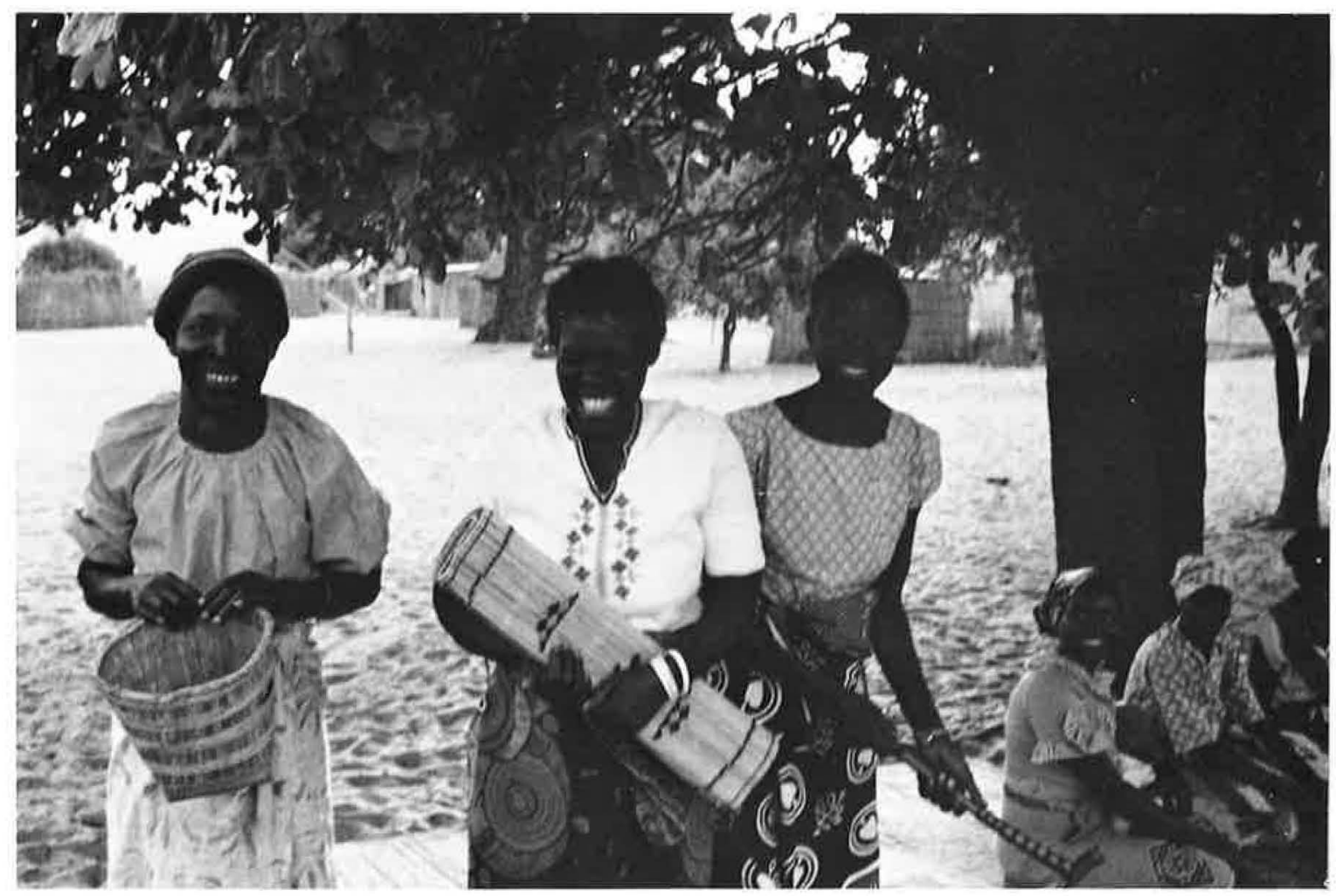


ognized that women might be farming under a different set of constraints or with different priorities than men. However, despite this mandate, team sociologist Gerben Vierstra notes that the concept of "women as an issue, or as our collaborators, did not really receive any attention in the Western Province until around 1987."

Including Women in Surveys and Trials. One of the first steps taken, with the encouragement of WEP, has been to ensure that ARPT surveys interview both female household heads and married women. A related but more difficult effort is to encourage the agricultural assistants to identify more women willing to participate in field trials. Knowledge of women's role in farming in many cases remains limited. For example, many agricultural assistants still remain totally unaware that there are households where women are farming alone. And for their part, women farmers are often reluctant to risk experimentation with their main food crops because their family's survival often depends on getting at least one good crop from their land. Women are most interested in experiments on crops that make the most money, (both modern and traditional vegetables), but these crops have not been the focus of the ARPT's work to date.

Professional Bias. Charles Kapekele Chileya, ARPT's socio-economist, confesses that when he began working with other scientists, "I was blind. I just went along with what the biological scientists saw. But then I did my Masters degree in the U.K., where we had an international group with a number of strong women students and teachers and an interdisciplinary approach. The women there convinced me I should pay attention to this aspect of rural life."

On his return to Zambia, he was at first disappointed at the reaction of his male colleagues to his new insight. His closest friend, an agricultural economist, argued with him: "We can't be doing this. Within any category of farmers, men and women are the same." But then, Kapekele Chileya adds with a laugh, "My friend showed his true colors when he said, 'Anyhow women farmers are not useful in economic analysis. You don't get good results because they don't plant in time!'"

Taking the Lead. By the end of 1987, the Provincial ARPT Coordinator, an agronomist, had learned enough to be convinced that women's participation was an issue to be considered. He asked Mr. Chileya to prepare a position paper that was well received within the Department. Now more emphasis is given to the benefits that women farmers might receive from the ARPT's work; for example, crops typically grown only by women such as bambara nuts, beans, cowpeas and groundnuts have begun to receive some attention. "This is a good move and we should do much more in this direction," states Mr. Chileya. "Crops like these fetch a high price and have excellent nutritional value. And any time the woman needs money, she can sell a small amount in the market or even to her neighbors."

Kapekele Chileya works closely with WEP to change attitudes within the Department. He makes sure, for example, that when the team lists the crops grown by farmers, the "minor" crops of importance to women do not get overlooked. And, if he cannot attend a staff meeting, he invites Mary Masona or Lydia Ndulu to take his place. If an agricultural assistant invites the team to attend a field day, he insists that ARPT will show up only if women farmers are going to be present.

Mr. Chileya also encourages ARPT and the trial assistants to work with the PPP groups. Doing experimental trials with women's groups not only benefits ARPT but the group as well, increasing the strength of their organization and increasing the profits earned from the sale of their crop.

Recognizing Diversity. Still, Kapekele Chileya feels that if ARPT is going to take women farmers seriously, it will have to stop talking of "the small farmer" as a man, or even of "femaleheaded households." "The ARPT has to recognize that the majority of its (potential) clients are women. But they are not all farming in the same way with the same resources. We have to be much more careful about defining who is doing what, and finding out what their needs and possibilities really are. We have to recognize that 'women' are not one thing: their needs are diverse."

\section{The Bureaucratic Change Process}

Advocacy. A key element in changing attitudes and developing special activities to help women farmers within the Department of Agriculture was the support of the Provincial Agricultural Officer (PAO) serving when the WEP program began. He defended and protected the concept and helped to establish "women farmers" as a legitimate professional concern. "Without him, we never could have opened the door", says Mary Masona. Promoted to a senior Ministry position in Lusaka, the former Provincial Agricultural Officer now provides an open channel for communicat- 


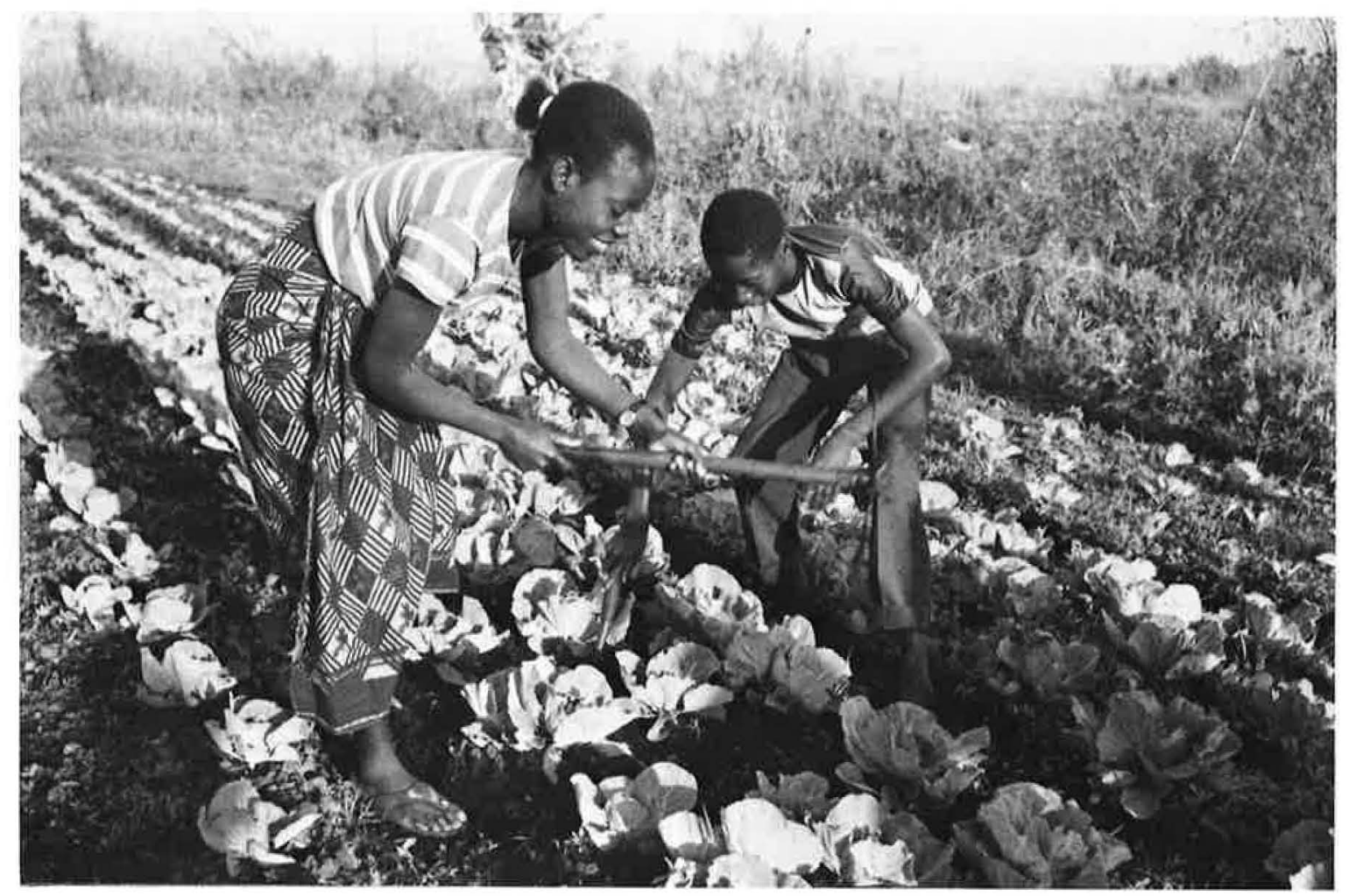

ing about the successes and difficulties of the WEP and the needs of women farmers at the national policy level.

The Importance of Data. On the other hand, the Assistant Provincial Agricultural Officer confesses that he worked in agricultural extension for a long time without considering special programs for women to be necessary or worthwhile. However, in 1985 he attended staff seminars on women in agriculture and was persuaded that some special effort was needed. "I thought at first the seminars would just be about somebody's opinions. But the survey data convinced me. It was the first time we had anything concrete to go on. I now read everything from the WEP or the ARPT that tells me more about women in farming in the province."

In April 1990 the Assistant Provincial Agricultural Officer conducted a small, random sample survey in two local government areas of Mongu District to investigate the work of the agricultural assistants. He found that none of the "contact farmers" selected by the AAs as their primary links with the farming community were women. "The criteria for farmer selection probably account for this," he comments. "Most women farmers don't have the indicators necessary to be selected. Maybe we should look at the indicators again."
But, he adds: "Personally, I believe that the group approach is the right way to go." Not only do groups help make the work of the agricultural assistants "cheaper per contact hour," but he speculates that, in the light of the fragile resources of the Department, women will have a better chance of sustaining their hard-won gains if they have a structure through which they can become somewhat self-reliant.

The Group Approach. The effectiveness of the group approach to extension and training has impressed WEP's colleagues at every level within the Department. The District Agricultural Officer for Mongu affirms: "We have seen so far that the idea of group promoter is very effective. Now we see every day that women, and men, are forming groups among themselves and that the AAs are encouraging them, even without a promoter to help them. In the old days, it was the women who did the work but the men got the training."

Seeing Is Believing. The District Agricultural Officer's own ideas changed in 1982-83 when he was working as an animal husbandry officer and saw women plowing for the first time. Today he is convinced: "If they have access to oxen and equipment, especially the women without a husband, they can plant on time and get a 
better crop.... Now, when we have shows, others are impressed when such women come with their groups to display what they have grown. They win a lot of prizes! This has a good effect on the thinking of the indunas (traditional leaders) and the people."

\section{Networking}

The WEP knows it needs the support of a wider group of colleagues. Often women's activities are marginalized, even within a supportive bureaucracy. Therefore, it is necessary to build personal relationships with senior civil servants and provide channels through which experiences can be exchanged and reviewed. Two network initiatives are of particular importance in legitimizing the issue of women in agriculture within the government bureaucracy: 1) establishment of Women Development Committees which draw together concerned women from various aspects of government service throughout the country and 2) government sponsored workshops for professional and technical staff at the provincial and district levels that share information and experiences related to women's roles in agriculture.

\section{Counting the Cost}

The provincial Department of Agriculture's own financial resources are meager. The Govern- ment spends on average between 400,000500,000 kwacha (U.S. $\$ 100,000-130,000$ ) each quarter to cover the recurrent costs of the Department's extension work. Projects financed by external donors contribute perhaps five times as much to the Department's total budget. Nevertheless, the success of any project depends on its being able to draw on the core resources of the Department itself.

The total budget for the PPP project, from 1986 to the end of 1990 , was U.S. $\$ 248,000$. The Department contributes the salaries of the district and provincial coordinators, part of the petrol and training costs, daily subsistence allowances for the AAs and a driver.

The annual costs of the PPP per district are modest. For example, the expenditure in Mongu District from January-December 1989 was 257,169 kwacha (under U.S. \$7000). Although the project has supplied motorbikes to each of its district coordinators, the bikes are not really suitable transportation, especially in the rainy season. PPP staff are often dependent on hitching rides on the District Agricultural Officer's vehicles, but when none is in operating condition, the PPP's own work gets stalled.

The Department contributes the coordinator's salary and an office for the WEP. Between 1983 to 1988 , the costs of what became the WEP

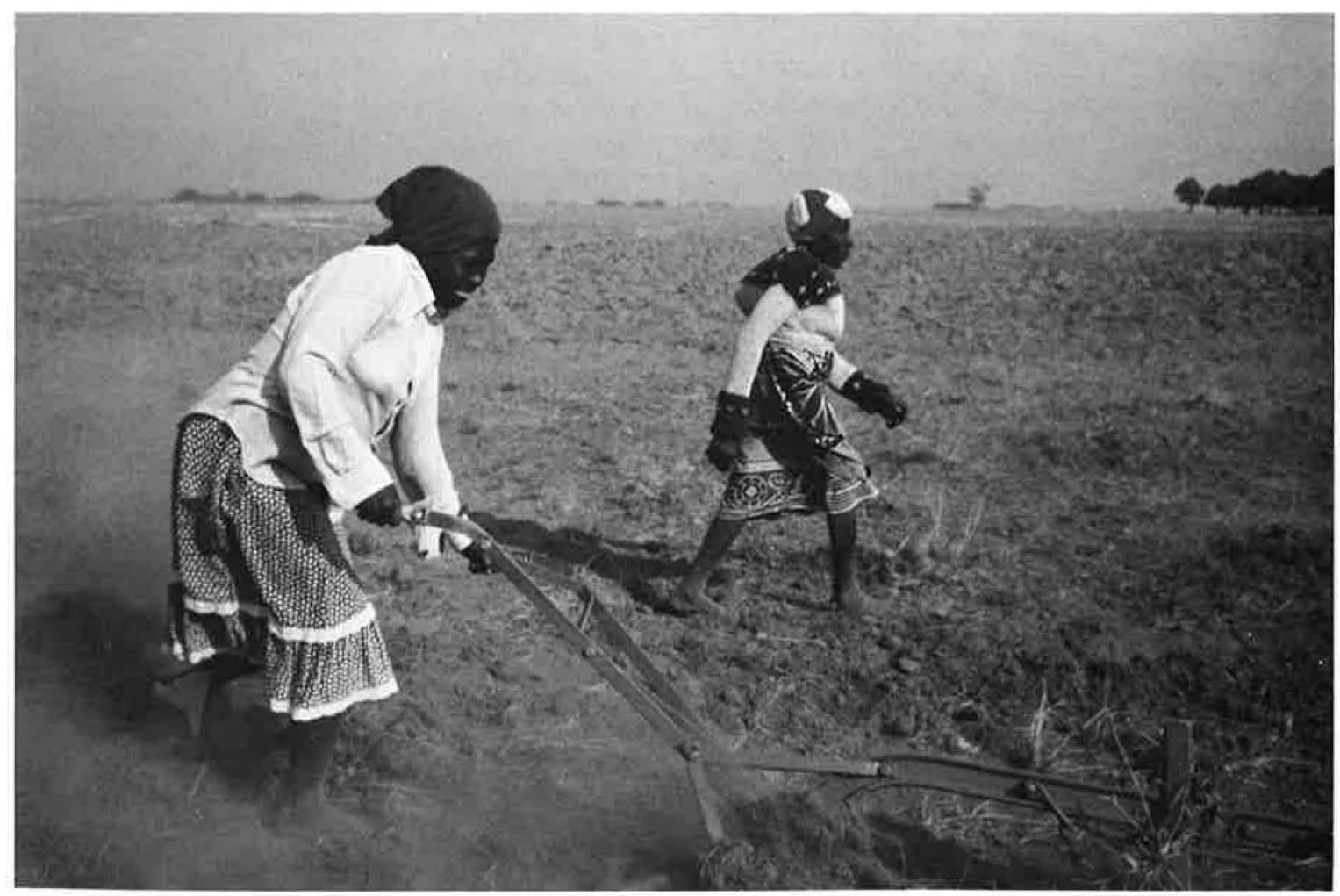


were absorbed under the Extension Training Program and ran at about U.S. $\$ 120,000$ per year. From 1989 through 1991, the budget totaled about U.S. $\$ 550,000-600,000$. This sum included the costs of expatriate researchers and consultants.

The PPP and WEP each have provided both female and male staff of the Department with opportunities to gain wider experience and training regarding women in agriculture within the region and internationally. The Provincial Agricultural Officer says that it has helped the Department press for change because it now realizes that neglecting women holds back the development of agriculture-a problem shared by many countries-and that practical solutions are possible.

\section{Facing the Future}

Last in Line When Resources Are Scarce. Contrary to initial expectations, the major problems facing the program have been logistical rather than attitudinal. Problems relating to custom, attitude, male-female relations and so forth are proving to be manageable, more so than the crippling budgetary limitations facing the Department as a whole. When resources are scarce, the WEP and its related activities receive the lowest priority. For example, there are not enough vehicles, fuel is expensive and sometimes scarce and maintenance is difficult. Support of groups and of agricultural assistants is thus less frequent or reliable than desired. The transport problem has constrained expansion to new areas, or to a larger number of groups and has also limited the number of times AAs and other staff have received training on issues relating to "women in agriculture."

Staffing Concerns. Sustaining group development also poses a difficult staffing problem. The group promoters currently mobilizing and organizing the women farmer groups cannot be absorbed into the government structure because of their low educational qualifications, yet they are essential to the whole approach. The Assistant Provincial Agricultural Officer points to another staffing issue that he has often discussed with women at headquarters: Too few women apply for jobs in the Department partly because few women enroll at the agricultural training colleges. Mrs. Masona notes that, "this is where the WEP comes in. We just have to convince our male colleagues to work with women farmers and provide them with the skills to do so."

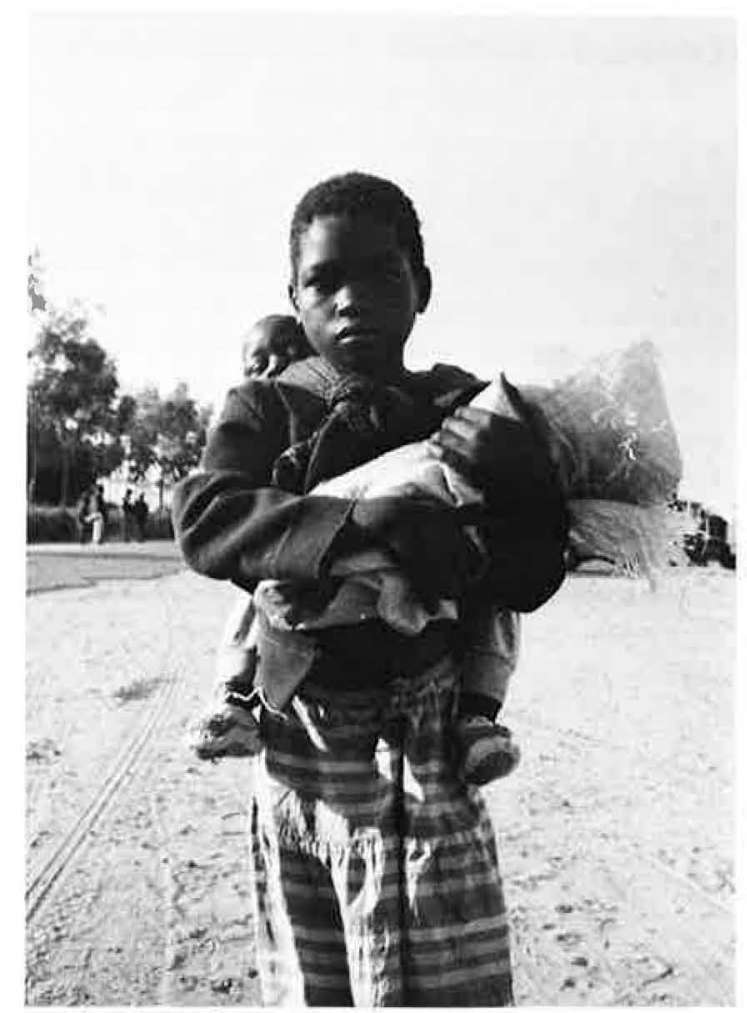

\section{Reviewing What Has Been Accomplished}

The main achievement of the WEP has been to launch a process of internal change within a conservative agricultural bureaucracy. It has relied largely on bringing about voluntary change in the behaviors and attitudes of male staff working in the mainstream units of the Department of Agriculture (Animal Husbandry and Engineering, Training, Agricultural Extension and Research). The experience shows that, with a dedicated staff and a clear vision of the strategic objectives, leverage is possible even when the locus is within a relatively powerless and marginalized unit such as the Home Economics Section. 


\section{Lessons Learned}

1. Incorporating the needs of women farmers into the mainstream of a traditional (male-dominated) agricultural bureaucracy requires a multifaceted approach. Persuasion, leverage, liaison and demonstration are all required to redefine mandates, incorporate gender perspectives in training, broaden research agendas, extend technical services to women and to encourage and support female farmers to expand their opportunities and perceptions.

2. When there is sufficient support within the higher echelons of large bureaucracies, even a small staff operating out of a relatively marginalized unit can be an effective agent for change. The leadership of the Provincial Agricultural Officer for the Western Province, along with the dedication and determination of key female staff in the Home Economics Section and the WEP and PPP programs, created a climate conducive to the establishment and nurturing of positive working relationships with other units carrying out mainstream agricultural extension activities. The experience of the WEP program demonstrates that neither a large budget nor the hiring of new cadres of personnel is required to make a significant difference when sufficient institutional support is present.

3. Although change from within is a slow and sometimes cumbersome process, it is essential to encourage evolution within a large bureaucracy while also creating a demand for change from outside. Incorporation of women as a focus was something the Department of Agriculture itself identified as a concern. Thus it could take pride in its leadership role in attempting to better address the needs of women farmers. Particularly in times of scarce resources, using an approach that encourages openness to change, rather than defensiveness, may be a more appropriate way to effect change. At the same time, building up demand at the grassroots level is critical to ensuring appropriate and effective delivery of services once the bureaucracy accepts that such services are warranted.

4. In addition to training and liaison, hard data and demonstrable results are persuasive ammunition that can do a lot to convince a traditional, male-dominated bureaucracy to take women's farming seriously-seeing is believing! This underscores the importance of including women farmers in research design, experimental field trials and data collection so that the results clearly demonstrate, in black and white, what women farmers are already doing, what they are capable of doing and how their needs differ from those of male farmers.

5. Bringing women together in groups can be an effective way of helping them gain access to extension services, empowering them to take initiatives and demand access to resources, and providing them with a network of mutual support - particularly important as more and more women become the sole support of families and traditional family/community bonds continue to erode. The group process creates a supportive environment that helps women to better define and effectively articulate the type of assistance they require even when their perceptions differ from what male extension staff think they need!

6. Given that agricultural extension agents are predominantly male and few resources exist that would allow for the training and hiring female agents, male agents can effectively provide services to women farmers if they are given proper, gender sensitive training, if they receive encouragement from respected colleagues (particularly other men) and if they can see for themselves what women are actually capable of doing. The establishment of farmers' groups also makes it easier for male field staff to work with women farmers as it overcomes their reluctance to interact on a one-to-one basis with a woman who is not a member of their family.

7. Although women's primary role as farmers requires a focus on access to mainstream agricultural extension services, development of non-farming, income-generating activities such as craft production and marketing can be a culturally acceptable strategy for getting women involved in groups as well as providing a needed source of cash income that can be used to fund farm investments. While such a strategy may be beneficial, and is non-threatening to both women and the community, it must not overshadow women's primary role as farmers.

8. Women can readily learn important, nontraditional skills-such as ox plowing-if they are given the necessary support and training. Once a core group of women have demonstrated their mastery of a formerly "male-only" task, and it becomes clear that access to these skills will substantially increase their productivity (and thus the welfare of the entire family) and does not threaten the role of men, the old prejudices and taboos about what women can and should do will begin to fade away.

9. Minimal reliance on expatriate funding 
and personnel may facilitate internal ownership of the change process within a bureaucracy. However, outside validation of an innovative concept, such as recognizing and supporting the role of women farmers, can be a critical factor that lends legitimacy to early efforts at the local level. In the Western Province, this was emphasized by the initial presence of a female expatriate expert and by
Mr. Chileya's exposure to new ideas during his tenure in the U.K. and his return to Zambia as an advocate for change. Awareness of the existence of a broad body of literature and experience on women's role in agriculture can provide support to programs seeking to address the needs of women farmers and help them to learn from experiences in other settings.

Figure 1

Organizational Chart

Department of Agriculture

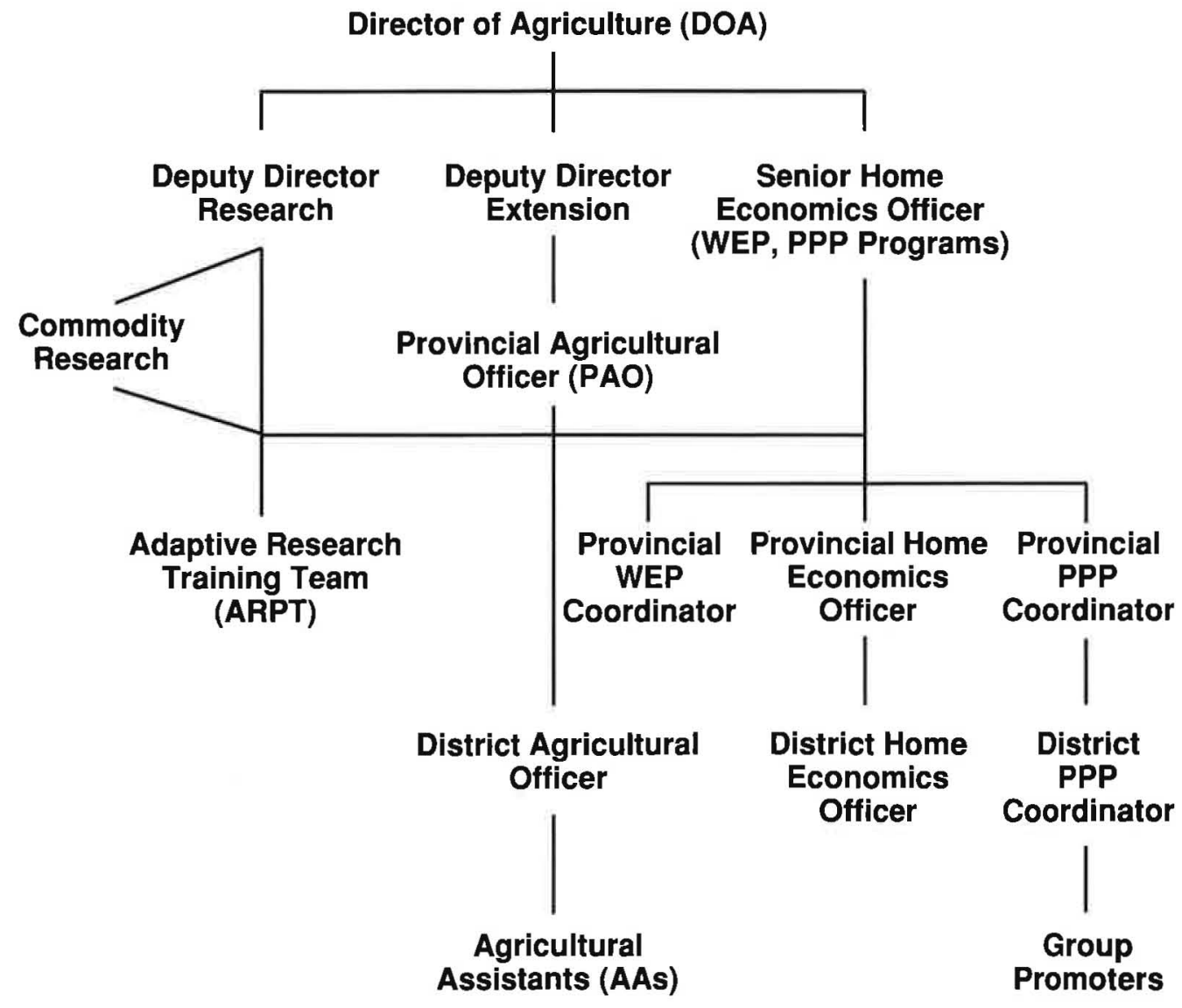




\section{Appendix}

The following publications document various aspects of integrating the needs of women farmers within agricultural extension programs. Please contact the publishers directly regarding availability, cost of publications and handling. Also listed are two programs providing short-term training courses on working with women farmers in Africa.

\section{Publications}

1) Working Together: Gender Analysis in Agriculture, Vol 1, Case Studies; Vol 2, Teaching Notes, by Hilary Sims Feldstein and Susan V. Poats, eds.; 2) Women's Roles and Gender Differences, series of seven African and two Asian case studies for planners; 3) The Impact of Male Outmigration on Women in Farming by Ingrid Palmer. (The Kumarian Press, 630 Oakwood Ave., Suite 119, West Hartford, CT 06110-1529, USA. Telephone: (203) 953-0214 FAX (203) 953-8579)

Women in Agriculture: What Development Can Do, by Myra Buvinic and Rekha Mehra, 1990. (ICRW, 1717 Massachusetts Ave., NW., Suite 302, Washington, D.C. 20036)

The Gender Variable in Agricultural Research, by H.S. Feldstein, C.B. Flora and S.V. Poats (Women in Development Unit, IDRC, Ottawa, Canada)

Using Male Research and Extension Personnel to Target Women Farmers by Anita Spring, 1987 (Women in International Development, Michigân State University, Working Paper No. 144)

Agricultural Extension for Women Farmers in Africa, by Katrine A. Saito and C. Jean Weidemann. World Bank Discussion Papers, No. 103 , 1990. World Bank Publications, Building 424, Raraitan Center, 80 Northfield Avenue, Edison, NJ 08818-7816, USA. Telephone: (908) 225-2165; FAX: (908) 417-0482)

Women and Livestock Production in Asia and the South Pacific Region by Alexandra Stephens,
RAPA Publication No. 1990/5. (Regional Office for Asia and the Pacific, FAO, Bangkok, Thailand)

Gender Issues in Farming Systems Research and Extension M. Schmink, S. Poats and A. Spring, eds. (Boulder, Colorado: Westview Press, 1988.)

\section{Training Programs}

Pan African Institute for Development (PAID), Kabwe East and Southern Africa

P.O. Box 80448

Kabwe, Zambia

Contact: Isaac Mungo, Course Coordinator

Short courses in areas of women in agriculture, women agricultural-extension agents, project planning, management and training

Eastern and Southern Africa Management Institute (ESAMI)

P.O.'Box 3030

Arustia, Tăhzania

Contact: Hilda Tadria

or *

P.O. Box 56628

Nairobi, Kenya

Short courses in development planning, management and women-an African perspective, women and marketing, women and research methodology, women and training 


\section{Other Editions of SEEDS Currently Available}

No. 2 Hanover Street: An Experiment to Train Women in Welding and Carpentry-Jamaica (Eng., Sp.)

No. 3 Market Women's Cooperatives: Giving Women Credit-Nicaragua (Sp., Fr.)

No. 4 Women and Handicrafts: Myth and Reality-International (Eng., Sp., Fr.)

No. 5 The Markala Cooperative: A New Approach to Traditional Economic Roles-Mali (Eng., Fr.)

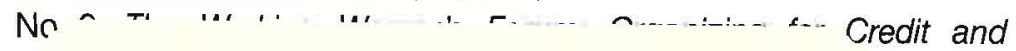

If you would like additional copies of this issue or any of the editions of SEEDS listed above, please write to us at the address given below. Copies of selected SEEDS issues in local languages are currently being published by organizations in the following countries: Egypt, India, Indonesia, Kenya, Nepal, Pakistan, Thailand and Vietnam. Please write to us for more information if you are interested in these materials.

$$
\begin{gathered}
\text { Ann Leonard, Editor } \\
\text { SEEDS } \\
\text { P.O. Box } 3923
\end{gathered}
$$




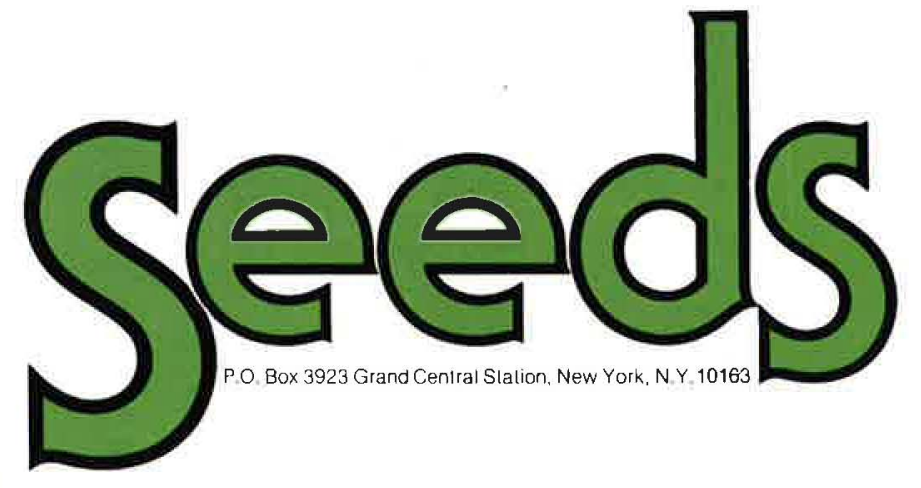

